\title{
Arts for Business: Creative Co-operation for Innovation and Sustainable Development of the Company as a Brand and Community
}

\author{
Katarzyna Szczepaniak
}

British Council

'Earth' without 'art' is just 'eh'

\begin{abstract}
In Poland, the value of art as a contributor and equal collaborator for business is still either not fully recognized or undervalued. Thus, the aim of the article is to present a set of effective practices and research, highlighting examples from Poland and focusing on areas of creative collaboration beneficial for entrepreneurs, such as employees' development and empowerment, artistic residences, and investing in artists seen as brands or simply hiring them as chief innovators and inspirers, not only instructors. Finally, the benefits in the field of human capital and communication are briefly discussed to encourage Polish business practitioners to strengthen and extend the art-business collaboration for the sake of the sustained socio-economic development.
\end{abstract}

Keywords: art, business, innovation, creativity, empowerment, employee development, self-leadership, CSR, brand identity, artistic residencies

\section{Introduction}

Going south of Finland, at schools we rarely learn connections between mathematics and dance, or language and logic, chemistry and art, not to mention that in the Polish educational system artistic classes are treated with negligence. This is particularly unfavourable for the business enterprise sector due to the fact that both business practitioners and researchers agree that the values and 
qualities sought after by entrepreneurs in today's world include innovation, creativity, empathy, the ability to think critically and holistically as well as to recognize alternative, unconventional solutions and to build relationships (e.g. The Economist Events, 2015). And these are the typical characteristics of the artistic community, where the creative process is an integral part of the everyday reality of people who paint, sculpt, compose, work on installations, visualizations, choreography, film or stage performance. Frequently, they struggle with financial difficulties and other constraints (socio-ethical, institutional) and nothing stimulates creativity as much as limitations, one of the most brilliant examples on our home market being the success of the Hoffland brand. Barbara Hoff designed clothes and accessories first for herself, in order to oppose the monotony of everyday fashion in the rationed reality of the People's Republic of Poland (PRL). Similarly to, although in a less revolutionary style than Coco Chanel, Hoff broke the existing norms and introduced a new quality, also social, and this is undoubtedly the aspiration of contemporary companies, for whom profit is not the only goal and who also want to be recognized actors in social life, not just economic one. Therefore, connections between the world of business and art are very important for both sides as well as for the society and require collaboration, which in the Western countries has been bringing visible results for years. It is also worth reminding that art was one of the factors that united the regenerating post-partition Poland, which was heavily diversified in economic terms. As Krzysztofowicz-Kozakowska writes, after regaining independence "the ruling elite recognized its [art's] special role in creating reality", and the priority issue was the participation of the young state in the world's fairs in order to appear on the international arena through the presentation of economic as well as artistic and cultural achievements, set at an equal level and closely related (2013, p. 6).

Despite the rich tradition of close cooperation between politicians, artists and entrepreneurs in the Second Polish Republic, nowadays, the spheres of art and business are stereotypically associated with two basic relationships: in the first one business is a sponsor or patron of artistic activities, while in the other art appears as a subject of financial investments due to the current value of works or potential one in the case of works by lesser-known artists. In both these relations, where art is reduced to the role of a 'recipient' or 'asset', there is hardly any space for active partnership aimed at joint creation or development of new solutions. The situation is similar with the perception of both worlds' representatives, who are often put in opposition in terms of personality traits. Thus, the main objective of the article is to disprove the myth that the only fields of business and art cooperation are the aforementioned examples. Another aim is to present the existing practices (e.g. Naiman, 2007; Strauß, 2017) and research (Lewandowska, 2015, 2016; Stern, 
2015), which show how much art and business can do together in a creative way, with particular emphasis on the active role of art in this relationship and on the resources of the broadly-understood artistic world, the business sector can draw from to develop qualitatively at many levels. This development also applies to the aforementioned features desirable in business, not only at top levels, but among all employed people, especially in the context of empowerment and self-leadership concepts, as the implementation of these translates into efficiency and positive perception of the brand (Randolph \& Blanchard, 2007).

As a result, the features and skills of outstanding entrepreneurs and artists will be addressed in the first place, for example, from in terms of their work seen as creative process in both cases. Next, the ways to develop these attributes thanks to art and other ways of cooperation between the two sectors, which in Poland are still little known or underestimated, will be presented. Finally, the selected benefits for business are to be discussed, with the main emphasis on the development of human capital for the sake of the internal cohesion of the employees, who are seen as a causative and efficient community thanks to increased communication skills and building stable, authentic relationships.

The above strategies and the forms of partnerships and cooperation between arts and business described in the article, such as artistic residencies, investing in a creator as a brand, employing artists in the innovation department, are aimed at encouraging Polish entrepreneurs and business theoreticians to draw from the rich experience existing in this area in the West to strengthen the inter-sectoral collaboration and sustainable development, both economic and social, in Poland, based on building brand awareness and perceiving the company as a community with a vast innovation potential.

\section{Qualities of successful people: the creator's code}

The theme of similarities between successful business people and great creators has been widely discussed for years. In 2012 Leberecht argued in the pages of Fortune that business can learn a lot from art, presenting as evidence the list of 12 attributes characteristic to artists. These features include passion, the ability to ask questions and contest the status quo, mental flexibility, authenticity, innovation, the ability to holistic, interdisciplinary thinking and the talent to take advantage of adversity. In turn, Wilkinson (2015), in search of the key to entrepreneurial success, conducted 200 interviews with women and men in managerial positions responsible for the successes of such companies as LinkedIn, PayPal, eBay, Spanx, Chipotle, Under Armour, JetBlue, SpaceX, Tesla Motors, 
Zipcar, Airbnb, Dropbox. The result of the research is the 'code of the creator', i.e. six features that the researcher chose based on her interviews. It is worth quoting them and expanding slightly to see the similarities between these two lists.

1. Find the gap. Recognizing things, solutions and possibilities that others cannot see for various reasons, i.e. the ability to perceive on a slightly different level, from a different perspective or holistic and contextual perception. Innovation in the approach to a given issue, at the mental level, is a key issue here.

2. Drive for daylight. Controlling the situation but looking forward in a bold and optimistic way and the ability to strive for the goal despite the adversity. Positive attitude helps to overcome difficult situations, and concentration on the future without nostalgia indicates the direction of 'here and now' action.

3. Fly the OODA loop. Quick decision-making based on the Observation-Orientation-Decision-Action cycle, i.e. a business strategy borrowed from the activities of the US Army becomes a guideline for parallel operations. Decision-making is then a multi-level process, requiring greater focus, but giving better insight into the situation and more adequate solutions.

4. Fail wisely. Learning from mistakes, even the costly ones, and drawing appropriate conclusions or ultimately turning them into success is another vital quality and in the world of art 'skilful failure management' seems to be a creative norm. According to Sloane (2003), Richard Branson has had this attitude in business from the beginning of his career, using the Edison's approach, i.e. looking at 'failure' as a valuable discovery of a method that did not work.

5. Network minds. Promotion and skilful management of the varied intellectual potential so that people with different talents, competences and ways of thinking can learn from one another and build new values or solutions. According to some authors, the management of creative or dynamic people is precisely the area where art can become a successful business (e.g. Daum, 2013). Lavy (2017) also emphasizes the role of leaders-artists, who manage people, in opposition to managers-craftsmen. who manage processes.

6. Gift small goods. Taking care of people by noticing their individual and purely human needs and responding to them increases the effectiveness of these people. Although in our culture, taking care of an employee seems to be something relatively new, and nurseries at the company's headquarters are still a 'revolutionary' solution, it is not a novelty in Polish history. In fact, Warsaw of the Second Polish Republic was a thriving city and one if its pillars was a dynamically developing entrepreneurship; Wedel Factory or Jabłkowski Brothers' House (in Polish: Dom Braci Jabłkowskich) had large numbers of loyal employees, both men and women, due to benefits, such as housing and 
education, provided to them and their families by the employers (Barbasiewicz, 2013). In Wilkinson's approach, however, little signs of genuine concern are important, a derivative of highly developed empathy.

The results of Wilkinson's research confirm the above-mentioned thesis by Leberecht (2012), which leads to the conclusion that people from the world of art can be very helpful in extracting or polishing those tangible benefits in business. It can be added that for the most part, these are aspects that we possess as children, and some of them are lost in the process of socialization, and therefore they are 'renewable resources', which, if necessary, can be retrieved with the help of specialists, who deal with creativity 'professionally', and successfully applied in business activities that undoubtedly require creativity. As Picasso claimed, every child is an artist, and the problem is how to maintain this feature when we grow up. If the word 'artist' is also the equivalent of our creative resources here, by working with arts and through the arts adults will be able to 'return to their roots' and achieve success. It is a widely used practice in many countries, thus it is worth taking a closer look at the experiences that bring numerous benefits to entrepreneurs.

\section{Arts for business in practice in the world and in Poland}

In the United States, since 2005 prizes have been awarded to entrepreneurs who in an innovative way contribute to the development of co-operation between the business sector and arts. This is an initiative by Americans for the Arts, a thriving non-profit organization founded in 1960, whose aim is to promote art in various spheres of life. In Europe, activities for partnership and building new forms of collaboration on the art-business axis were conducted, among others, by the organization Arts and Business UK (Lewandowska, 2016). On the other hand, the EU Council in the cultural work schedule for 2015-2018 took the following points as Priority C: European agenda for culture: Culture as a catalyst for creativity and Europe 2020 strategy: Intelligent and sustainable economic growth based on intersectoral co-operation, "to stimulate innovation, economic stability and social inclusion" (DUUE, 2014). As experience shows, the forms of this cooperation can be diverse, and for the purpose of the article five key points will be discussed, supported by specific examples of activities that can serve as models or inspirations for entrepreneurs on the Polish market. 


\section{Creative workshops as an investment in employees' development}

Employees' development through various types of training is nothing new. However, what is offered by workshops based on strategies drawn from the world of art, is the in-depth quality, where the focus is on people with their creative potential and its individual development as well as authentic relationships based on sound communication and team development. Linda Neiman, the founder of Creativity at Work, whose clients include US Navy, GE, American Express, RBC, Intel and BASF, has been conducting such activities since 1995 and emphasizes that a high level of innovation is the result of creative atmosphere at work, creating space and providing appropriate tools to groups of people with diverse talents. Therefore, the natural choice here is to use the resources from the arts world, and the 70 scenarios that she proposed which develop leadership skills, interpersonal, communicative, critical and holistic thinking are based on painting, drawing, theatre (impro), poetry and prose (storytelling) or sculpture (VanGundy and Naiman, 2007).

In Poland, Magdalena Kąkolewska, a founder of the Art Transfer Foundation, the initiator of the Arts for Business programme and also the leader of Hestia Artistic Journey Foundation established in 2014, has been running such a pioneering activity since 2012. The Ergo Hestia Group is also an example of a company that, as part of cooperation with the artistic sector, has introduced broadly-understood education through art to its activities. One of the artists whose work inspires also other business representatives to creative activities is Kacper Kowalski, whose work can be found, among others on www.kacperkowalski.com. His unusual approach to photography, including taking pictures from a paraglider and depicting a world that 'we know' well, force viewers to exercise mentally, for Polish landscapes seen from a height of 150 metres often resemble the work of radical abstractionists. Therefore, it is a natural starting point to change the approach and alternative look at what is 'obvious' in business practice.

\section{A new perspective: employing people from the artistic sector in the company}

The presence of artists in business, especially from the world of music, is a very common phenomenon. It refers both to investing in other people's ideas or enterprises and to establishing own music companies, recording studios as well 
as creating clothing and cosmetic brands. Such people in the West include, among others, Madonna, Jay-Z, Beyonce, Victoria Beckham and Shepard Fairey. There are also people with artistic education, who are extremely successful in other markets than creative ones, for example, Joe Gebbia, a graduate of the Rhode Island School of Design and co-founder of the innovative solution of accommodation services known as Airbnb. What is relatively recent, however, is employing by corporations artists who provide a new insight and who, thanks to their personal brand, help to reach new audiences. In the case of well-known personalities, this latter aspect may obscure the essence of the former one. Stull, the indisputable resource of artists is their innovation they bring due to their way of thinking, working or communicating contents. The flagship example is the employment of the musician Will.i.am, or William James Adams, founder of the band Black Eyed Peas as the creative director by Intel in 2011. In 2014, Will.i.am was in turn responsible for the production of the new generation printers in Systems3D company, where he implemented pro-ecological projects, consistent with his personal value system, thus building a positive image of the brand as socially responsible (Hogan, 2015). Apart from innovation, this is undoubtedly another added value of such a partnership.

\section{Artistic projects under CSR for the benefit of the local community}

The role of arts as a motor of social change is recognized at the global level, which is reflected in the activities of the World Economic Forum. The WEF website features a permanent column of Art and Culture, where we read that good art teaches empathy, and empathy leads to changes, which world leaders are becoming increasingly aware of (Obaid-Chinoy, 2017). For many companies, collaboration with the artistic community under CSR is often the next stage after sponsorship. This was the case for such companies as Rolls Royce or BMW, which supports, for instance, London's Tate Modern. Ellen Andrea Seehusen (Karabell, 2015) managed these processes and, in the context of her experience on the international arena, she emphasizes cultural differences in the approach to CSR itself. Seehusen points out that, for example, in Germany, the individual development of employees through creative activities based on art or visits at the theatre is also part of the corporate social responsibility programme.

Since the issue of the of the artistic circles' participation in CSR is a fairly widely practiced area of cooperation between arts, business and the third sector, this part of the article is limited to sources of knowledge about experiences in 
this field and related reflections. This includes a report from a survey conducted by Americans for the Arts among companies cooperating with the world of arts: American Express, Boeing, Aetna, Adobe Foundation, Microsoft, StubHub, Applied Materials, Deutsche Bank Americas Foundation (Stern, 2015), as well as Berlin's Product \& Vision project from 2005, i.e. several months of collaboration between one company and 14 arts representatives (Strauß, 2017). The invaluable contribution to the current discussion on the situation in Poland is provided by Lewandowska's research $(2015,2016)$, which shows the areas of arts and business cooperation, including the explicit position of CSR, and describes changes in these relations and benefits for entrepreneurs, which will be discussed further.

\section{Residence programmes for artists}

In Poland, residence programmes are still associated with cultural institutions and occasionally with non-governmental organisations. On the website artistresidencies.pl/pl/programy-rezydencyjne, supervised by is the National Centre for Culture in Poland and the Centre for Contemporary Art at Ujazdowski Castle, as of 10/02/2018 there was no reference to a single artistic residence programme organised by a business entity. Meanwhile, in 2015, Segran claimed that almost all companies initiate residential programmes, listing Facebook, Siemens, Amtrak, Autodesk, and Honeywell. According to Segran, the diversity of programmes is immense, but the common denominator is usually the solution proposed by the artists as a result of such a residence. For example, the Threadless company, a T-shirt producer, organizes a programme for the graffiti creator, which results in printing patterns on T-shirts. However, there are also less direct ways to use the creators' potential; in case of the programme for Autodesk, more people from the artistic world took part in it and their task was simply to use the given Autodesk tool, and their experiments and unconventional ideas for usage were invaluable inspiration to develop a specific application. Finally, there are also more obvious cases of residences, as a result of which a sculpture or extraordinary hotel interior is to be created.

\section{Investing in artists as entrepreneurs}

Agnes Janich is a young Polish artist and businesswoman, as she combined these two domains, and her income is largely based on the sale of her own works, which cost 2.3-2.5 thousand Swiss francs each (Wąsowski, 2017). She works 
internationally and also advises collectors-millionaires on expanding their collections. In an interview with Business Insider Poland, she is devastated by the Polish stereotype of a 'poor artist' that impedes the development of the local arts market and damages the collector's assets, for the works of artists do not even reach the equivalent of prices that are the norm in the West. Thus, the key issue here is mentality and attitude change, i.e. noticing the financial potential of the artist seen as a brand, and consequently extensive investment by business entities not only in the works, but also in the creator (their development, materials, studio, etc.), which will bring long-term benefits for a given company and contribute to the development of the arts market, bringing Poland closer to the standards efficiently functioning in other countries and raising the economic status of people from the arts sector.

This need is also expressed by people who want to make money on their work, which was shown, among others, by the 2013 and 2015 competitions with the Virgin Mobile Academy education programme under the slogan Art of Business and Business for Arts, and in the 2017 Krakow Art Business Festival, organised by the Student Forum Business Centre Club Foundation. As can be seen, this is the space for a redefined, deeper type of business investment patronage aimed at the activities and development of creators, both the aspiring and the mature ones. Some of them decide to embed their artistic actions within the business activity in order to operate on a wider scale, implementing their specific visions, and to facilitate cooperation with potential investors (not patrons or sponsors). Karolina Gruszka and Iwan Wyrypajew may serve as example here, as in 2017 they founded the Weda Produkcje company, and their successes are the subject of congratulations for investors as well as encouragement for other entrepreneurs to create similar partnerships with various artists.

\section{Benefits for business}

In her pioneering research on the Polish market, Lewandowska (2015) showed specific areas in which benefits are taken by companies cooperating with representatives of the artistic world. Interviews with 239 business entities showed that companies entering such collaborations value creative partnerships and that they result in increased levels of engagement, creativity and knowledge, especially if people from the company are actively involved in the processes of artistic creation and positive relationships with both the local community and shareholders. An important element in building relationships is also the new quality of communication thanks to the interaction with arts, which is invaluable 
in the internal and external processes of the company. Below there is a brief description of the selected benefits, also based on other sources, not covering the issue but starting further discussions and exploration, for example on the use of the language of emotions in business, which is an inherent component of messages in arts and the reception of artistic works.

\section{The use of human capital: empowerment through art}

Randolph and Blanchard (2007) emphasize the role of the factor, or rather the system that strengthens the employees of the company, which in the Polish translation is maintained in its original form: empowerment. It is a way of thinking and management that provides actual space for the employees to use their versatile potential. According to the authors, empowerment is creating a climate that frees the unused knowledge, experience and motivation in employees. And these resources are innumerable, because they come from various fields where individuals function, and also versatile, as indicated by Gardner's theory of multiple types of intelligence (1983).

Strengthening at the individual level translates into above-average results of the whole company, as indicated by Buzan, Dottino and Israel (2008) who claim that enterprises must be able to use the knowledge and creativity of every employee in order to be successful in the modern global market. The authors justify that also those who have contact with the customer, sellers, in the production of goods or services are familiar with problems and solutions to everyday issues, which is why the fate and social perception of the brand depend on the employees' internal integration and creativity. Thus, if the management is mindful and focused on the quality development, it will take into account the aspect of the company environment as an important factor affecting the functioning of the individual and secure the harmony of this arrangement, ensuring contact with arts. As Vygotsky and his followers postulated, thanks to the release of feelings and emotions both in the process of creation and reception, "art can become an effective instrument for the integration of human personality" and "contributes to the harmonisation of the psyche, thus restoring the balance between the individual and the social environment" (Szkołut, 1997, pp. 301-302). Consequently, if appropriate contact with arts becomes a constant element of professional activities, its cathartic function may foster internal integration and strengthening at the individual level, which is an invaluable resource for the employer. 


\section{Verbal communication}

Communication is one of the key skills that business people can acquire from the world of art to communicate in a more comprehensive and eloquent manner (Schumpeter, 2011). Developing a skilful, honest and engaging narrative has therefore become an important training topic. One of the proponents of this trend, Stephen Denning (2005), postulates developing storytelling skills. The significance of the traditional storytelling is emphasized by the research of the neuroeconomist Paul Zak (Monarth, 2014), which shows biological reactions to a well-told story: in the moments of tension cortisol, a stress hormone, is released and stimulates concentration, whereas fragments of a story with an emotional flavour, increase the release of oxytocin, i.e. a hormone responsible for the sense of belonging and empathy. Additionally, stories with a happy ending stimulate the release of dopamine, which increases the positive attitude of the recipient, optimism and - what is important - trust, a major factor for the business entity. Therefore, it is vital to implement in the business communication, in the internal and external dimension of the company, quality in the narrative, which is typical for artistic fields: authors writing prose and poetry, film and performances scripts. Opening the business to cooperation with artists will expand the range of competences of the employees useful at work and outside working environment.

\section{Non-verbal communication}

Nevertheless, storytelling is not confined to the choice of words. It also involves paralanguage i.e. intonation, speech rate, tone of voice, etc., which play a significant role in the message perception. Other aspects of non-verbal communication include the body language, for example, gestures, mime, eye-contact, body posture, the way of sitting, walking etc. Studies by Cuddy, Wilmuth and Carney (2012) reveal that the awareness of own body language may be also used to boost self-confidence prior to stressful and challenging work-related situations. Since for people dealing with performing arts body and voice are the tools of the trade, their support in the development of these specific skills, including the coherent combination of the verbal and non-verbal dimension, is the next dimension of cooperation between art and business. Obviously, there is the crucial element of visual communication in marketing, though its broader range is worth keeping in mind. It refers to messages delivered indirectly (e-mails: layout, front, attachments), or those we use live (presentation slides) as well as the direct messages senders themselves 
(physical appearance, including outfit and its colours, makeup). For this reason, individuals involved in acting, performance, choreography, artistic make-up, set design may be invaluable coaching support and inspiration to change common harmful habits connected with non-verbal communication, the latter being seriously neglected element in universal education.

\section{Strengthening the bonds: relations or Relations?}

Already Maslow in his research (e.g. 1986) on human needs emphasized that the desire of group belonging is one of the basic human needs. Small or large-sized companies are examples of various social groups with specific corporate cultures. The issue to be solved at the management level is the quality of this culture: is it a community to which an employee belongs only formally or is it a group that an individual identifies with and has a sense of close bond. The socio-emotional attachment becomes a focal concept, as the person engaged in acting in favour of their own team may develop stronger relations with other team members, which, in turn, is reflected in the efficacy and productivity of the team. As Randolph and Blanchard claim (2007), efficient organizations are those with employees exhibiting active approach, who are engaged, applying self-leadership. The latter results from the already mentioned culture of empowerment and is made possible due to the effective internal team communication. The art becomes the means to increase communicative competencies, especially in the areas where qualitative relations are involved. As Janich, the artist mentioned earlier states: “(...) in life, these are people who are most important. Listen to people. It's worth it, indeed" (Wąsowski, 2017).

\section{Conclusion}

In 2017, the Polish government spent $€ 100 \mathrm{~m}$ on the Czartoryski art collection, simultaneously liquidating art schools and neglecting current social and market demands despite the education reform being introduced at that time (Madej, 2017). Therefore, the responsibility for satisfying the real educational demand for creativity falls on the employers' shoulders if they want to achieve their business goals at the highest possible level. In order to change the intellectual status quo in one's company, it is worth undertaking a challenge and inviting artists as collaborators, who use different formats and codes of communication. In fact, the communication between the worlds of arts and business may be difficult at start 
due to the cultural differences in both settings and shortage of such practices in Poland. Yet, this 'intercultural communication' is a challenge worth the time and resources, as it brings the outcomes described above which cannot be achieved by traditional training methods. Both arts and exchange of goods or services have been rooted in human social life since the dawn of the species. thus, since the human being is a common denominator it is worth investing in their creative development. Moreover, not only do the benefits of cooperation with the artistic world mentioned here apply to business, but they also refer to other sectors and their entities, where organizational cultures may require refreshing and human capital may be in need of sustainable management.

\section{References}

Barbasiewicz, M. (2013). Ludzieinteresu w przedwojennej Polsce. Przedsiębiorcy, filantropi, kapitaliści. Warszawa: PWN.

Buzan, T., Dottino T., Israel R. (2008). Zwykli ludzie - liderzy. Jak maksymalnie wykorzystać kreatywność pracowników. Warszawa: Muza SA.

Cuddy, A.J.C., Wilmuth, C.A., Carney D.R. (2012). The Benefit of Power Posing Before a High-Stakes Social Evaluation. Harvard Business School Working Paper, 13-27.

Daum, K. (7.06.2013). 4 Great Leadership Lessons from the Arts. Retrieved from: https://www.inc.com/kevin-daum/4-great-leadership-lessons-from-the-arts. html (accessed: 12.1.2018).

Denning, S. (2005). The Leaders's Guide to Storytelling. Mastering the Art and Discipline of Business Narrative. San Francisco: Jossey-Bass.

DUUE (2014, December 23). Konkluzje Rady i przedstawicieli rządów państw członkowskich zebranych $w$ Radzie $w$ sprawie planu prac $w$ dziedzinie kultury na lata 2015-2018. Dziennik Urzędowy Unii Europejskiej. Retrieved from: http://eur-lex.europa.eu/ legal-content/PL/TXT/?uri=CELEX\%3A52014XG1223(02) (accessed: 13.1.2018).

VanGundy, A, Naiman, L. (2007). Orchestrating Collaboration at Work: Using Music, Improv, Storytelling, and Other Arts to Improve Teamwork. Book Surge Publishing.

Obaid-Chinoy, S. (2017, January 4). How can artists lead dramatic social change? World Economic Forum. Retrieved from: https://www.weforum.org/agenda/2017/01/ how-can-artists-lead-dramatic-social-change/ (accessed: 1.2.2018).

Hogan, M. (2015, March 8). Will.i.am: 3D printing will revolutionise society. In 20 years, you'll be able to print a new kidney. The Guardian. Retrieved from: https://www.theguardian.com/music/2015/mar/08/will-i-am-ekocycle-recycling -plastic-bottles. (accessed: 13.1.2018).

Karabell, S. (2015). Leadership Stage craft: Why Art Is Good for Business. Forbes. Retrieved from: https://www.forbes.com/sites/shelliekarabell/2015/09/14/lea 
dership-stagecraft-why-art-is-good-for-business/2/\#6e2622524569 (accessed: 12.1.2013).

Krzysztofowicz-Kozakowska, S. (2013). Sztuka II RP. Olszanica: BOSZ. Lavy, I. (2017). Leadership Framed by Art. Iris Lavy.

Leberecht, T. (2012, December 21). What entrepreneurs can learn from artists. Fortune. Retrieved from: http://fortune.com/2012/12/21/ what-entrepreneurs-can-learn-from-artists/ (accessed: 21.1.2018).

Lewandowska, K. (2015). From Sponsorship to Partnership in Arts and Business Relations. The Journal of Arts Management, Law, and Society, 45, 33-50.

Lewandowska, K. (2016). It's not all about the profit: analysis of changes in arts and business relations. Economics and Business Review, 2, 107-126.

Madej, E. (2017, January 23). W przeszłość zamiast w przyszłość - kultura i sztuka Polski w XXI wieku - jak reforma edukacji uderza w dzieci wybitne.... Gazeta Wyborcza. Retrieved from: http://wyborcza.pl/7,95891,21259131,w-przeszlosc-zamiast-w-przyszlosc-kultura-i-sztuka-polski.html (accessed: 13.1.2018).

Maslow, A. (1986). W stronę psychologii istnienia. Warszawa: Instytut Wydawniczy PAX. Monarth, H. (2014, March 11). The Irresistible Power of Storytelling as a Strategic Business Tool. Harvard Business Review. Retrieved from: https://hbr.org/2014/03/ the-irresistible-power-of-storytelling-as-a-strategic-business-tool (accessed: 13.1.2018).

Randolph, A, Blanchard, K. (2007). Kluczem jest empowerment. In: W.K. Blanchard (Ed.) Przywództwo wyższego stopnia. Warszawa: PWN, 75-81.

Schumpeter (2011, February 17). Business has much to learn from the arts [online].

The Economist. Retrieved from: http://www.economist.com/node/18175675 (accessed: 13.1.2018).

Sloane, P. (2003). Twórcze myślenie w zarządzaniu. Gdańsk: GWP.

Segran, E. (2015, October 3). Welcome to the Brave New World of the Corporate-Sponsored Artist. Fast Company. Retrieved from: https://www.fastcompany.com/3043276/ welcome-to-the-brave-new-world-of-the-corporate-sponsored-artist (accessed: 1.2.2018).

Strauß, A. (2017). Dialogues between Art and Business: Collaborations, Co-optations, and Autonomy in a Knowledge Society. Cambridge: Cambridge Scholars Publishing.

Stern, L.E. (2015). Corporate Social Responsibility and The Arts. Americans for the Arts. Retrieved from: http://animatingdemocracy.org/sites/default/files/CSR Report_FINAL.pdf (accessed: 1.2.2018).

Szkołut, T. (1997). Ponadestetyczny sens sztuki. Lublin: Wyd. Uniwersytetu M. Curie-Skłodowskiej.

Wąsowski, M. (2017, January 22). Przyjaźń z artystą może być korzystna dla biznesmena. Business Insider Polska. Retrieved from: https://businessinsider.com. pl/firmy/zarzadzanie/sztuka-i-biznes-czego-biznesmen-moze-nauczyc-sie-od-ar tysty/zkcljmm (accessed: 1.2.2018). 
Wilkinson, A. (2015). The Creator's Code: The Six Essential Skills of Extraordinary Entrepreneurs. New York: Simon \& Schuster.

The Economist Events. (2015, April14). Oxford-style debate Proposition: Entrepreneurs are born, not trained. Innovation Forum. Retrieved from: https://youtu.be/ xBIgfXK_FhU (accessed: 2.1.2018).

\section{Katarzyna Szczepaniak}

MA in linguistics, psychologist; the main areas of interest are broadly understood social communication, identity, sustainable individual and group development, social and communicative role of art. As a lecturer and educator, she cooperates, among others, with the SWPS University of Social Sciences and Humanities, the University of Warsaw, Collegium Civitas and the Museum of Modern Art and the Art Transfer Foundation. A founder and coordinator of the socio-educational initiative Akademia Znajomych; currently works as a Partnerships and Projects Manager at the British Council in the Education \& Society department as a coordinator of the Polish-British academic collaboration. 